\title{
Apatite Deposition on Calcium Alginate Fibres in Simulated Body Fluid
}

\author{
Tadashi KOKUBO, Masayuki HANAKAWA, ${ }^{*}$ Masakazu KAWASHITA, ${ }^{* *}$ Masahiko MINODA, ${ }^{* * *}$ \\ Toshiyuki BEPPU, ${ }^{* * * *}$ Takeaki MIYAMOTO ${ }^{* * * *}$ and Takashi NAKAMURA***** \\ Research Institute for Science and Technology, Chubu University, 1200, Matsumoto-cho, Kasugai-shi, Aichi 487-8501 \\ *Department of Material Chemistry, Graduate School of Engineering, Kyoto University, Nishikyo-ku, Kyoto-shi 615-8510 \\ **Ion Beam Engineering Experimental Laboratory, Graduate School of Engineering, Kyoto University, Nishikyo-ku, Kyoto-shi 615-8510 \\ ***Department of Chemistry and Materials Technology, Faculty of Engineering and Design, Kyoto Institute of Technology, \\ Sakyo-ku, Kyoto-shi 606-8585 \\ *****Matsue National College of Technology, 14-4, Nishiikuma, Matsue-shi 690-8518 \\ *****Department of Orthopaedic Surgery, Graduate School of Medicine, Kyoto University, Shogoin, Sakyo-ku, Kyoto-shi 606-8507
}

\author{
擬似体液中におけるアルギン酸カルシウム繊維へのアパタイト形成 \\ 小久保 正·花川正行* . 川下将一** . 箕田雅彦*** . 別府俊幸****. 宮本武明**** . 中村孝志***** \\ 中部大学総合工学研究所, 487-8501 愛知県春日市松本町 1200 \\ *京都大学大学院工学研究科材料化学専攻, 615-8510 京都市西京区京都大学桂 \\ **京都大学大学院工学研究科附属イオン工学実験施設, 615-8510 京都市西京区京都大学桂 \\ ***京都工芸繊維大学工芸学部物質工学科, 606-8585 京都市左京区松ヶ崎 \\ ****松江工業高等専門学校, 690-8518 松江市西生馬町 14-4 \\ *****京都大学医学研究科整形外科, 606-8507 京都市左京区聖護院川原町
}

\begin{abstract}
Calcium alginate fibres with an average diameter of $5 \mu \mathrm{m}$ were prepared by extruding an aqueous sodium alginate solution through nozzles with holes of $0.1 \mathrm{~mm}$ diameter into an aqueous calcium chloride solution, and then through a calcium chloride methanol solution. The ratio of D-mannuronate $(M)$ to $L$-gluronate $(G)$ subunits in the calcium alginate ranged from 0.7 to 2.0 . The fibres were soaked in an aqueous saturated calcium hydroxide solution for $5 \mathrm{~d}$, and then soaked in a simulated body fluid (SBF) with ion concentrations nearly equal to those of human blood plasma. Fibres with an $M / G$ ratio of 2.0 had apatite deposited on their surfaces within $7 \mathrm{~d}$ in SBF, but fibres with $\mathrm{M} / \mathrm{G}$ ratios of 0.7 and 1.5 did not. The higher apatite-forming ability of the former fibres was attributed to their release of more calcium ions from the fibres, that is, the formation of a larger number of free carboxyl groups, effective for apatite nucleation and more efficient acceleration of the apatite nucleation by increasing the ionic activity product of the apatite in SBF.
\end{abstract}

[Received December 22, 2003; Accepted April 27, 2004]

Key-words : Apatite, Calcium alginate fibres, Carboxyl groups, Biomimetic process, Simulated body fluid

1. Introduction

Some ceramics such as Bioglass ${ }^{\circledR}$, sintered hydroxyapatite, and glass-ceramic A-W implanted into bone defects form a bonelike apatite layer on their surfaces in the living body and tightly bond to surrounding bone through this apatite layer. These ceramics are called bioactive ceramics and are in clinical use as important bone graft materials. ${ }^{1)}$ However, they have poor fracture toughness in comparison with human cortical bone. Recently, metals such as titanium and tantalum and their alloys have been shown to form bonelike apatite on their surfaces and bond to the surrounding bone if they had been previously subjected to alkali and heat treatment. ${ }^{2), 3)}$ These metals are used clinically as bone substitutes under load-bearing conditions, as they have higher fracture toughness. They are, however, too high in elastic moduli in comparison with human cortical bone.

Natural bone is a composite in which nano-sized bone minerals are deposited on organic collagen fibres fabricated into a three-dimensional structure. It is expected that such a composite could be prepared by a biomimetic process in which synthetic organic fibres are fabricated into a three-dimensional structure analogous to that of the collagen fibres in natural bone, modified with functional groups effective for apatite nucleation on their surfaces, and soaked in a simulated body fluid (SBF) with ion concentrations nearly equal to those of human blood plasma.

Tanahashi et al. made the first attempt to prepare such a composite by a biomimetic process in 1994. ${ }^{4)}$ They aimed at producing $\mathrm{Si}-\mathrm{OH}$ groups effective for apatite nucleation on the surfaces of organic polymers by exposing them to $\mathrm{CaO}-$ $\mathrm{SiO}_{2}$-based glass particles in SBF. The resulting apatite formation was restricted to the surface of the polymers exposed to the glass particles. Recently, Oyane et al. succeeded in uniform deposition of nano-sized bonelike apatite on the surface of ethylene-vinyl alcohol copolymer $(\mathrm{EVOH})$ fibres in SBF by modifying the surface of the EVOH fibres with a silane coupling agent and calcium silicate or anatase-type titania. $^{5), 6)}$

We have shown that organic polymer gels containing carboxyl groups also deposit bonelike apatite on their surfaces in SBF if they are previously treated with an aqueous $\mathrm{Ca}(\mathrm{OH})_{2}$ solution. ${ }^{7)}$ Alginic acid generally consists of L-gluronate $(\mathrm{G})$ and D-mannuronate (M) subunits, both of which contain carboxyl groups (Fig. 1). In this study, calcium alginate fibres with different $\mathrm{M} / \mathrm{G}$ ratios were prepared and their apatiteforming abilities in SBF were examined to reveal the fundamental conditions for obtaining nanoapatite-organic polymer fibre composites with a structure analogous to that of natural bone. 


\section{Experimental}

2.1 Preparation of calcium alginate fibres

Sodium alginates $(4.0 \mathrm{~g})$ with $\mathrm{M} / \mathrm{G}$ ratios ranging from 0.7 to 2.0 (Kimitsu Chemical Industries Co., Ltd., Tokyo) were dissolved in $80 \mathrm{ml}$ of distilled water in a polystyrene bottle and kept for $1 \mathrm{~d}$. Fifteen grams of $\mathrm{CaCl}_{2}$ (Nacalai Tesque, Kyoto) was dissolved in $500 \mathrm{ml}$ of distilled water to obtain an aqueous $3 \% \mathrm{CaCl}_{2}$ solution. Three hundred millilitres of aqueous $\mathrm{CaCl}_{2}$ solution was mixed with an equal volume of methanol (Wako Pure Chemical Industries, Ltd., Osaka). The aqueous sodium alginate/methanol ( $1 / 1)$ solutions thus prepared were extruded into $500 \mathrm{ml}$ of the $3 \%$ aqueous $\mathrm{CaCl}_{2}$ solution through a nozzle with 50 holes of $0.1 \mathrm{~mm}$ diameter, under a pressure of $3.92 \mathrm{~N} \cdot \mathrm{cm}^{-2}$, and then passed through $500 \mathrm{ml}$ of aqueous $\mathrm{CaCl}_{2} /$ methanol solution, and spun by being passed through two rollers rotating at $10.9 \mathrm{~m} \cdot \mathrm{min}^{-1}$ and $12.4 \mathrm{~m} \cdot$ $\min ^{-1}$, respectively (Fig. 2) ${ }^{8)}$ The fibres were kept in a $1 \%$ $\mathrm{CaCl}_{2}$ solution.

\subsection{Treatment with $\mathrm{Ca}(\mathrm{OH})_{2}$ solution}

Fibres were cut using a steel knife and formed into a bundle $20 \times 10 \times 1 \mathrm{~mm}^{3}$, and then washed with distilled water. One gram of $\mathrm{Ca}(\mathrm{OH})_{2}$ (Wako Pure Chemicals Industries, Ltd., Osaka) was dissolved in $300 \mathrm{ml}$ of distilled water in a polystyrene bottle, stirred for $1 \mathrm{~h}$ at room temperature, and then kept for a further $1 \mathrm{~h}$ under nitrogen gas. The top, clear layer of the

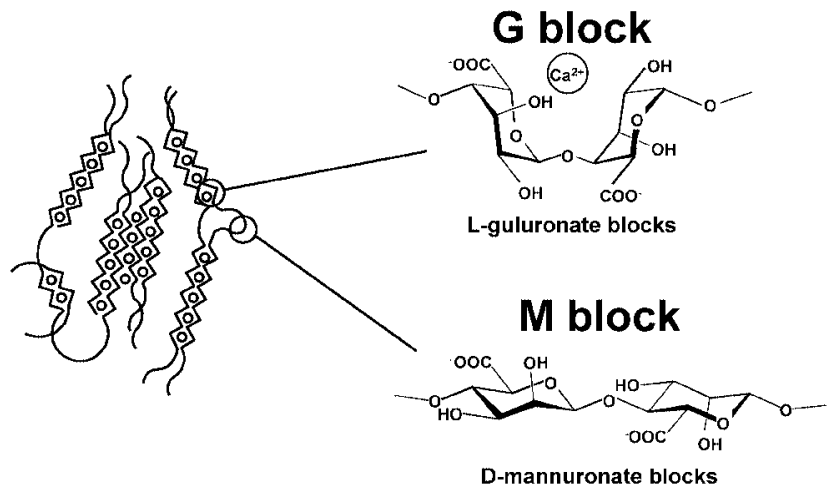

Fig. 1. Schematic representation of calcium alginate gel.

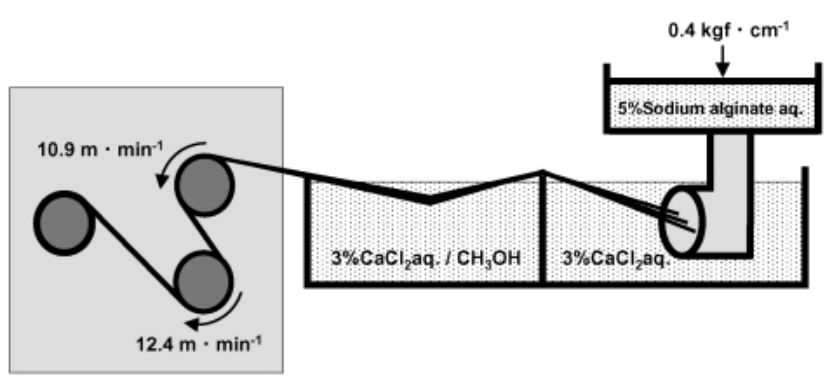

Fig. 2. Spinning of alginate fibres. solution was passed through a filter (MILLEX $^{\circledR}-\mathrm{HV}$, Millipore Corporation) with a pore size of $0.45 \mu \mathrm{m}$. The alginate fibre bundles were immersed in the saturated aqueous $\mathrm{Ca}(\mathrm{OH})_{2}$ solution and kept under nitrogen for $5 \mathrm{~d}$.

\subsection{Soaking in SBF}

The alginate fibre bundles treated with the saturated $\mathrm{Ca}(\mathrm{OH})_{2}$ aqueous solution were soaked in $40 \mathrm{ml}$ of a simulated body fluid (SBF) with ion concentrations nearly equal to those of human blood plasma (Table 1), ${ }^{9)}$ at $\mathrm{pH} 7.40$ and $36.5^{\circ} \mathrm{C}$. After various periods, the fibres were taken from the $\mathrm{SBF}$, kept in $40 \mathrm{ml}$ of distilled water for $1 \mathrm{~d}$, washed and dried at room temperature.

2.4 Analysis of fibres and SBF

The structure of the calcium alginate fibres was analyzed with Fourier-transform infrared attenuated total reflective spectroscopy (FT-IR ATR; Magna 860, Nicolet Instrument Co., Madison, WI, USA). The incident angle was $45^{\circ}$. Zinc selenide was used as an internal reflection element.

The surface structures of the calcium alginate fibres after soaking in SBF were analysed by thin-film X-ray diffractometry (TF-XRD; RINT2500, Rigaku, Co., Tokyo) and fieldemission scanning electron microscopy (FE-SEM; S-4700, Hitachi Ltd., Tokyo) with an attached energy dispersive X-ray spectroscope (EDX; EMAX-7000, Horiba, Ltd., Kyoto).

Variations in the element concentrations of the SBF arising from the soaking of the calcium alginate fibres were measured using inductively coupled plasma atomic emission spectroscopy (ICP; SPS-1500VR, Seiko Instruments Inc., Chiba).

\subsection{Structure of fibres}

\section{Results}

For all examined $\mathrm{M} / \mathrm{G}$ ratios, long uniform alginate fibres with average diameter of $5 \mu \mathrm{m}$ were prepared.

Figure 3 shows FT-IR ATR spectra of the newly prepared fibres with different $M / G$ ratios. All fibres show one broad

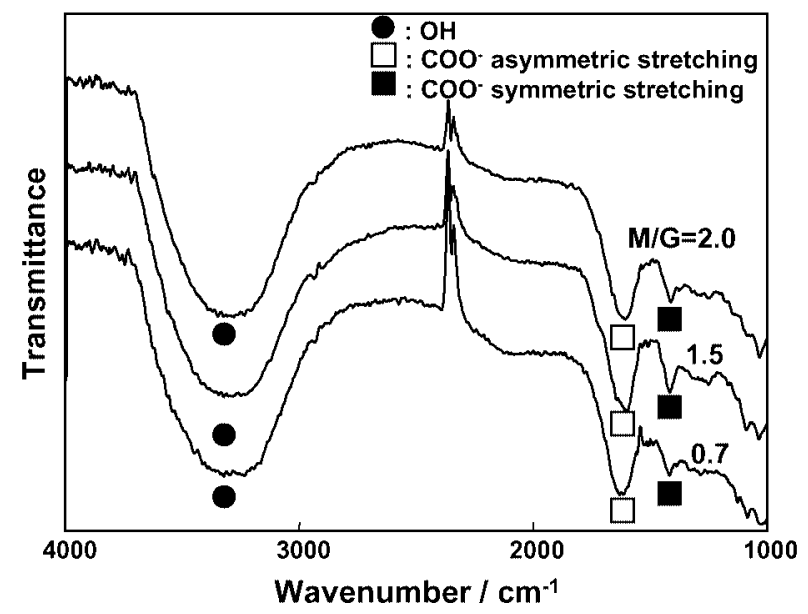

Fig. 3. FT-IR ATR spectra of the surfaces of alginate fibres with various $\mathrm{M} / \mathrm{G}$ ratios.

Table 1. Ion Concentrations of Simulated Body Fluid (SBF) and Human Blood Plasma

\begin{tabular}{cccccccccc}
\hline & \multicolumn{7}{c}{ Ion concentration / mM } \\
\cline { 2 - 9 } & $\mathrm{Na}^{+}$ & $\mathrm{K}^{+}$ & $\mathrm{Mg}^{2+}$ & $\mathrm{Ca}^{2+}$ & $\mathrm{Cl}^{-}$ & $\mathrm{HCO}_{3}{ }^{-}$ & $\mathrm{HPO}_{4}{ }^{2-}$ & $\mathrm{SO}_{4}{ }^{2-}$ \\
\hline SBF & 142.0 & 5.0 & 1.5 & 2.5 & 148.8 & 4.2 & 1.0 & 0.5 \\
Human blood plasma & 142.0 & 5.0 & 1.5 & 2.5 & 103.0 & 27.0 & 1.0 & 0.5 \\
\hline
\end{tabular}




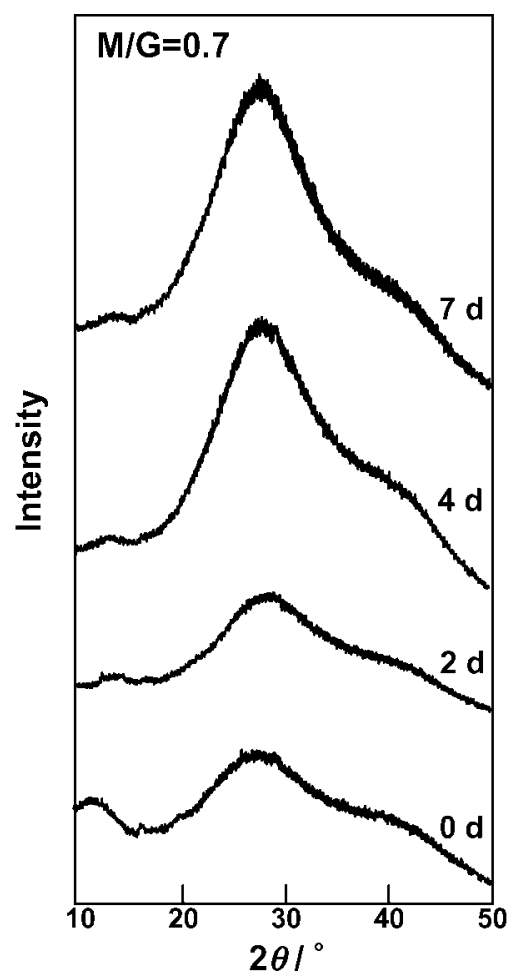

Fig. 4

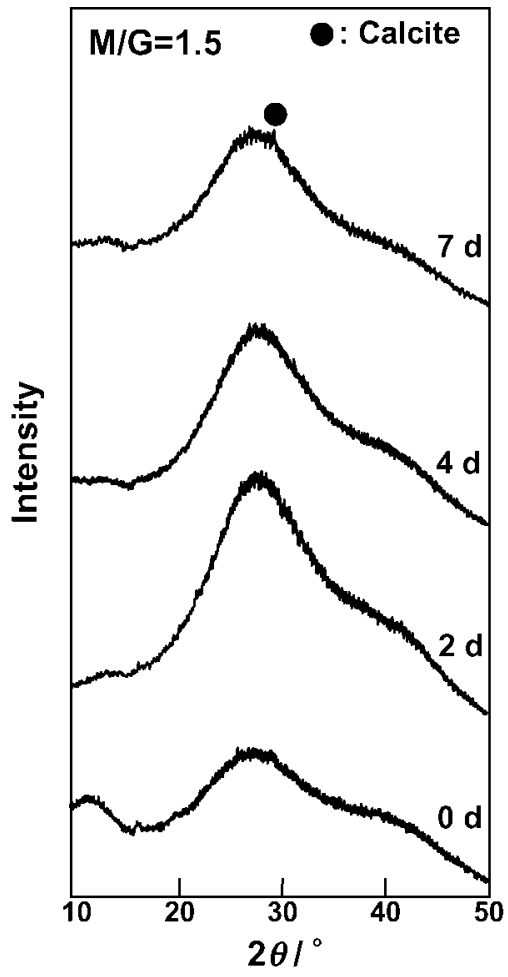

Fig. 5

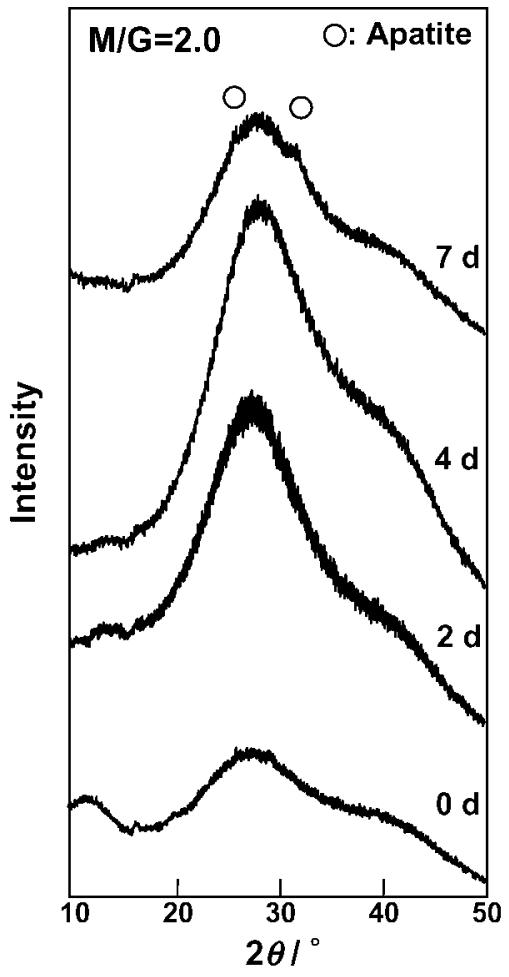

Fig. 6

Fig. 4. TF-XRD patterns of the surfaces of alginate $(\mathrm{M} / \mathrm{G}=0.7)$ fibres that had been soaked in $\mathrm{SBF}$ for various periods after treatment with saturated $\mathrm{Ca}(\mathrm{OH})_{2}$ solution.

Fig. 5. TF-XRD patterns of the surfaces of alginate $(\mathrm{M} / \mathrm{G}=1.5)$ fibres that had been soaked in $\mathrm{SBF}$ for various periods after treatment with saturated $\mathrm{Ca}(\mathrm{OH})_{2}$ solution.

Fig. 6. TF-XRD patterns of the surfaces of alginate $(\mathrm{M} / \mathrm{G}=2.0)$ fibres that had been soaked in $\mathrm{SBF}$ for various periods after treatment with saturated $\mathrm{Ca}(\mathrm{OH})_{2}$ solution.

absorption peak at around $3300 \mathrm{~cm}^{-1}$ and two sharp absorption peaks at 1680 and $1400 \mathrm{~cm}^{-1}$. The broad absorption peak is ascribed to vibrations of $\mathrm{OH}$ groups. ${ }^{10)}$ The two sharp absorptions are respectively, ascribed to the asymmetric and symmetric stretching vibrations of the carboxylate ion. This indicates that all the alginate fibres contained a considerable concentration of carboxylate ions.

3.2 Apatite deposition on fibers

Figures 4 to 6 show TF-XRD patterns of the surfaces of calcium alginate fibres with different $M / G$ ratios after being treated with the saturated $\mathrm{Ca}(\mathrm{OH})_{2}$ solution and then soaked in $\mathrm{SBF}$ for various periods. Calcium alginate fibres with $\mathrm{M} / \mathrm{G}$ ratios of 1.5 and 2.0 gave small peaks, ascribed to calcite and apatite, respectively, after soaking in SBF for $7 \mathrm{~d}$, whereas no peak was observed for the fibres with an $\mathrm{M} / \mathrm{G}$ ratio of 0.7 , even after soaking in SBF for $7 \mathrm{~d}$. Figures 7 to 9 show SEM photographs of the surfaces of the calcium alginate fibres with different $M / G$ ratios after being treated with the saturated $\mathrm{Ca}(\mathrm{OH})_{2}$ solution and then soaked in $\mathrm{SBF}$ for various periods. EDX analysis of surfaces of the calcium alginate fibres showed the existence of calcium and phosphorus on fibres with $\mathrm{M} / \mathrm{G}$ ratios of 1.5 and 2.0 after soaking in SBF for $7 \mathrm{~d}$, but no phosphorus on fibres with an $\mathrm{M} / \mathrm{G}$ ratio of 0.7 , even after soaking in SBF for $7 \mathrm{~d}$. These results mean that alginate fibres with $\mathrm{M} / \mathrm{G}$ ratios above 1.5 formed calcium phosphate such as apatite or amorphous calcium phosphate on their surfaces within $7 \mathrm{~d}$ in SBF, whereas no calcium phosphate formed on fibres with an $\mathrm{M} / \mathrm{G}$ ratio below 0.7 .

\subsection{Element concentration of SBF}

Figure 10 shows the time-variation of calcium and phosphorus concentrations in SBF following soaking of calcium alginate fibres with different $\mathrm{M} / \mathrm{G}$ ratios that had been previously treated with the saturated $\mathrm{Ca}(\mathrm{OH})_{2}$ aqueous solution. All fibres induced an increase in calcium concentration at an early stage, but the fibres with $\mathrm{M} / \mathrm{G}$ ratios of 1.5 and 2.0 showed a decrease in the calcium concentration at later stages. On the other hand, the fibres with $\mathrm{M} / \mathrm{G}$ ratio of $0.7 \mathrm{did}$ not show this change. The increase and the decrease were both greater for the fibres with higher $\mathrm{M} / \mathrm{G}$ ratios. The phosphorus concentration in the SBF decreased with increasing soaking time for the fibres with $\mathrm{M} / \mathrm{G}$ ratios of 1.5 and 2.0, but did not change for the fibres with an $\mathrm{M} / \mathrm{G}$ ratio of 0.7 . The magnitude of the decrease in phosphorus concentration was also larger for fibres having higher $M / G$ ratios.

\section{Discussion}

Our results show that calcium alginate fibres with an $\mathrm{M} / \mathrm{G}$ ratio of 2.0 form apatite on their surfaces, but those with an $\mathrm{M} / \mathrm{G}$ ratio of 1.5 form calcite with a small amount of apatite and/or amorphous phosphate on their surfaces, and those an $\mathrm{M} / \mathrm{G}$ ratio of 0.7 form no apatite on their surfaces in SBF. The formation of calcite on the surface of fibres with an $M / G$ ratio of 1.5 might be attributed that the calcium ions reacted with carbonate gas in air, which were remained on the fibre surface because of the insufficiency in the rinse of the fibre.

The high apatite-forming ability for the fibres having higher $\mathrm{M} / \mathrm{G}$ ratios may be attributed to the release of a large amount 


\section{$M / G=0.7$}
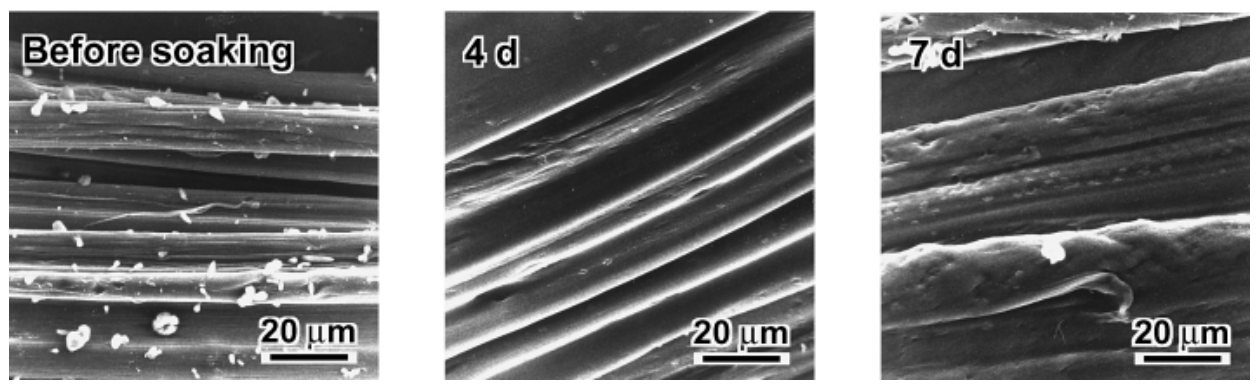

Fig. 7. SEM photographs of the surfaces of alginate $(\mathrm{M} / \mathrm{G}=0.7)$ fibres that had been soaked in $\mathrm{SBF}$ for various periods after treatment with saturated $\mathrm{Ca}(\mathrm{OH})_{2}$ solution.

\section{$M / G=1.5$}
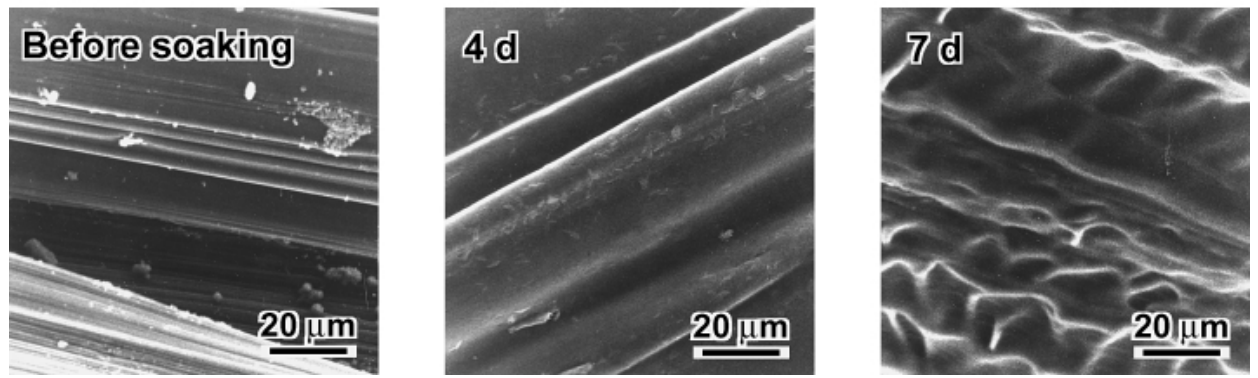

Fig. 8. SEM photographs of the surfaces of alginate $(M / G=1.5)$ fibres that had been soaked in $\mathrm{SBF}$ for various periods after treatment with saturated $\mathrm{Ca}(\mathrm{OH})_{2}$ solution.

\section{$M / G=2.0$}
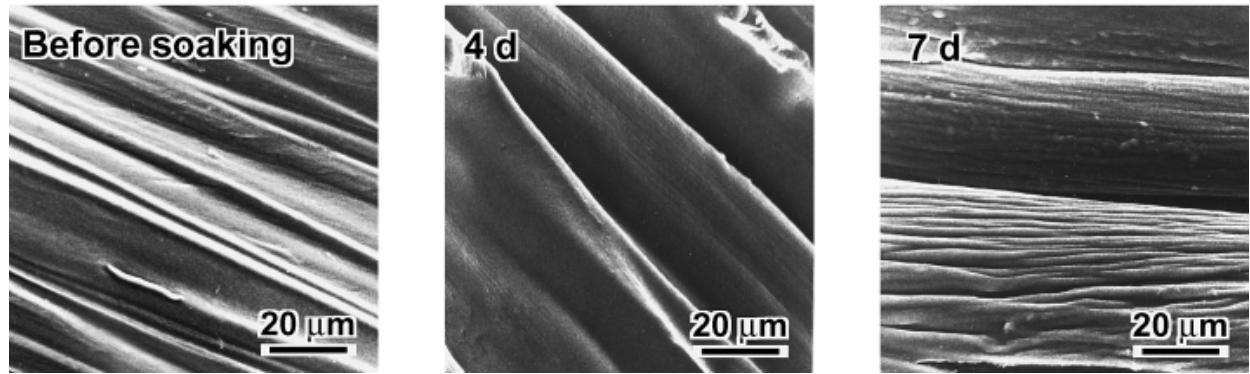

Fig. 9. SEM photographs of the surfaces of alginate $(\mathrm{M} / \mathrm{G}=2.0)$ fibres that had been soaked in $\mathrm{SBF}$ for various periods after treatment with saturated $\mathrm{Ca}(\mathrm{OH})_{2}$ solution.
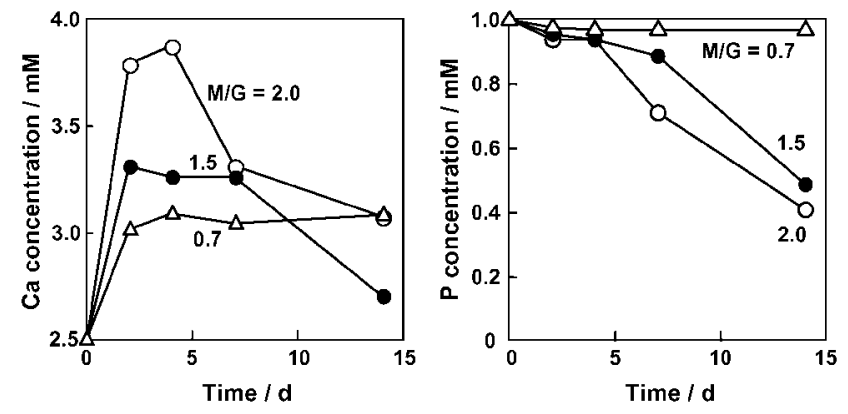

Fig. 10. Variations in $\mathrm{Ca}$ and $\mathrm{P}$ concentrations of SBF following soaking of alginate fibres with different $\mathrm{M} / \mathrm{G}$ ratios that had been treated with saturated $\mathrm{Ca}(\mathrm{OH})_{2}$ solution. of calcium ions from the fibres, as shown in Fig. 10. The release of large amounts of calcium ions means that the fibres form many free carboxyl groups on the fibre surface; these are effective for apatite nucleation ${ }^{11)}$ and more effectively accelerate apatite nucleation by increasing the ionic activity product of the apatite in SBF. Once the apatite nuclei form, they can grow spontaneously by consuming calcium and phosphate ions from the SBF, as shown by decreases in the calcium and phosphorus concentrations in SBF in the later stages (Fig. 10).

The fibres with higher $\mathrm{M} / \mathrm{G}$ ratios release more calcium ions because the calcium ions are weakly bonded to the carboxyl groups in the M subunits, whereas they are strongly bonded to the $\mathrm{G}$ subunits (Fig. 1). 
On the other hand, the mechanical strength of the calcium alginate fibres decreases with increasing $M / G$ ratio, because the fraction of ionic cross-linking by calcium ions decreases. Consequently, from a practical point of view, the $\mathrm{M} / \mathrm{G}$ ratio is limited to values below 2.0.

\section{Summary}

Calcium alginate fibres of $5 \mu \mathrm{m}$ in average diameter were prepared by extruding aqueous sodium alginate solutions into an aqueous calcium chloride solution, and treatment with an aqueous saturated $\mathrm{Ca}(\mathrm{OH})_{2}$ solution. The fibres obtained had apatite deposited on their surfaces within $7 \mathrm{~d}$ in SBF when the $\mathrm{M} / \mathrm{G}$ ratio was 2.0. More calcium ions were released into the $\mathrm{SBF}$ from the fibres with higher $\mathrm{M} / \mathrm{G}$ ratios, and the fibres formed more free carboxyl groups on their surfaces. These carboxyl groups were effective for apatite nucleation, and accelerated the nucleation and growth of the apatite by increasing the ionic activity product of the apatite in SBF.

Acknowledgement This research was partially supported by a Grant-in-Aid for Scientific Research (C), 13680934, Japan Society for the Promotion of Science.

\section{References}

1) Hench, L. L., “An Introduction to Bioceramics," Ed. by Hench L. L. and Wilson J., World Scientific, Singapore (1993).
2) Kim, H.-M., Miyaji, F., Kokubo, T. and Nakamura, T., J. Biomed. Mater. Res., Vol. 32, pp. 409-417 (1996).

3) Miyazaki, T., Kim, H.-M., Miyaji, F., Kokubo, T. and Kato, H., J. Biomed. Mater. Res., Vol. 50, pp. 35-42 (2000).

4) Tanahashi, M., Yao, T., Kokubo, T., Minoda, M., Miyamoto, T., Nakamura, T. and Yamamuro, T., J. Am. Ceram. Soc., Vol. 77, pp. 2805-2808 (1994).

5) Oyane, A., Kawashita, M., Nakanishi, K., Kokubo, T., Minoda, M., Miyamoto, T. and Nakamura, T., Biomaterials, Vol. 24, pp. 1729-1735 (2003).

6) Oyane, A., Kawashita, M., Kokubo, T., Minoda, M., Miyamoto, T. and Nakamura, T., J. Ceram. Soc. Japan, Vol. 110, pp. 248-254 (2002).

7) Kawashita, M., Nakao, M., Minoda, M., Kim, H.-M., Beppu, T., Miyamoto, T., Kokubo, T. and Nakamura, T., Biomaterials, Vol. 24, pp. 2477-2484 (2003).

8) Tamura, H., Tsuruta, Y. and Tokura, S., Sen-i Gakkai Preprints, F-151 (1998).

9) Kokubo, T., Kushitani, H., Sakka, S., Kitsugi, T. and Yamamuro, T., J. Biomed. Mater. Res., Vol. 24, pp. 721-734 (1990).

10) Silverstein, R. M., Bassler, G. C. and Morrill, T. C., "Spectrometric Identification of Organic Compounds, Fourth Edition," translated by Araki, S., Masuko, Y. and Yamamoto, O., Tokyo Kagaku Dozin, Tokyo (1983) pp. 90-90.

11) Tanahashi, M. and Matsuda, T., J. Biomed. Mater. Res., Vol. 34, pp. 305-315 (1997). 